\title{
Emma, Luiza i inne, czyli bovaryzm w Portugalii i Brazylii
}

W naszej kulturze - a mam tu na myśli kulturę zachodniej i wschodniej Europy, kulturę obu Ameryk, Australii, a także kulturę części Afryki i Azji - Madame Bovary jest nieusuwalna i nie da się jej niczym zastapić, a gdyby nagle przestała istnieć, gdyby jakimś zrządzeniem losu lub wyrokiem sądu zniknęła z prywatnych i publicznych bibliotek oraz $z$ internetu, część tej kultury natychmiast stałaby się dla nas całkowicie niezrozumiała.

Przestalibyśmy rozumieć niektóre książki i filmy, przestalibyśmy także w jakiejś części rozumieć samych siebie - w tym zakresie naszego istnienia, który po raz pierwszy został wypowiedziany właśnie w powieści Flauberta.

Renata Lis, Ręka Flauberta, Wydawnictwo Sic!, Warszawa 2012, s. 157.

\section{Bovaryzm a "straszny mieszczanin" między romantyzmem a realizmem}

O Gustawie Flaubercie (urodzonym 12 grudnia 1821 w Rouen, zmarłym 8 maja 1880 w Croisset) powieściopisarzu francuskim, uważanym za pierwszego przedstawiciela naturalizmu i jednego z najwybitniejszych mistrzów literatury francuskiej i światowej, napisano w Polsce dużo; pisarzom towarzyszyli tłumacze i eseiści, wtórowali im pilnie akademicy, autorzy wstępów i tekstów posłowia do kolejnych tłumaczeń. Nadal jednak literacka, psychologiczna, filozoficzna i socjologiczna kwestia bovaryzmu w Portugalii i Brazylii nie została na gruncie

* Dr hab., prof., Uniwersytet Warszawski, Instytutu Studiów Iberyjskich i Iberoamerykańskich, Zakład Języka i Kultury luzo-brazylijskiej, ul. Oboźna 8, 02-033 Warszawa, e-mail: a.kalewska@uw.edu.pl

1 Bovaryzm (fr.: le bovarysme, port.: o bovarismo) - termin utworzony w 1892 r. przez Jules'a de Gaultiera, od nazwiska bohaterki powieści Gustawa Flauberta Madame Bovary, oznaczający niezgodną z rzeczywistością postawę tytułowej bohaterki, czytelniczki sentymentalnych romantycznych powieści; mrzonki i marzenia wzięte za rzeczywistość. Au rebours dyskursu powieś- 
polskim obszerniej przedstawiona. Francusko-portugalsko-brazylijska intertekstualność i interkulturowość wymaga na gruncie polskim przedstawienia w formie ujmującej recepcję Flauberta w Portugalii i Brazylii. Podejmujemy zatem zadanie wpisania Pani Bovary (Madame Bovary, 1857) Flauberta i Kuzyna Bazylego (O Primo Basílio, 1878) Eçy de Queirós ${ }^{2}$ w kontekst badań nad historią literatury i kultury dwu najważniejszych krajów języka portugalskiego, pytając o związki dzieła z życiem społeczno-kulturalnym metropolii nad Tagiem i w dawnej największej portugalskiej kolonii, zwanej Brazylią od nazwy drewna brezylkowego (pau brasil) i bardzo chętnie odwiedzanej przez miłośników samby i antropologów kultury. Słusznie pisze wybitny polski romanista:

Powszechnie wiadomo, że Flaubert, fanatyk swojego rzemiosła, stworzył wzory klasycznej sztuki powieściopisarskiej. Rozumie się przez to, że doprowadził do szczytu metodę odziedziczoną głównie po Balzacu i w ten sposób zamknął - co prawda będąc jednocześnie prekursorem naturalizmu - okres, którego początek przypada na okolice roku 1830. „Z trzech największych twórców powieści w epoce mieszczańskiej - mówi Henryk Mann - Balzac jest postacią bohaterską, Stendhal pisarzem zawsze współczesnym. Świętym powieściopisarstwa jest natomiast Flaubert. Nie dokonał, jak Balzac, odważnych i dalekich wypraw do wszystkich nowych krajów świata, który dopiero co uległ gwałtownemu przekształceniu. Nie odkrył też, jak Stendhal, co będą odczuwać kobiety i mężczyźni przeszło sto lat po nim i po jego postaciach. Ale jak żaden inny pisarz przyczynił się do wewnętrznego i technicznego udoskonalenia powieści, której poświęcił siebie i swoje osobiste szczęście, jak gdyby działał pod nakazem zobowiązania zaciągniętego wobec instancji nadziemskich”3.

Autor Pani Bovary zainspirował pisarzy języka portugalskiego: Eçę de Queirósa w Portugalii i Machada de Assisa w Brazylii, jak również całą plejadę powieścio-

ciowego, bovaryzm to również próba realnego zaistnienia bohaterki, niezależnie od wyobraźni pisarza, która ją stworzyła. Psychologiczna konieczność deformacji własnych działań w chwili ich rzeczywistego poznania, także repetytywna wyobraźniowość i mistyczny sensualizm w filozofii. M. Moisés, Dicionário de Termos Literários, Cultrix, São Paulo 2004, s. 57-58.

2 Queiroz Eça de - dawna (i do współczesności anglofońska) pisownia nazwiska portugalskiego pisarza i dyplomaty José Maria de Eça de Queirós w zapisie bibliograficznym; w artykule w języku polskim stosujemy wersję współczesną.

3 Maciej Żurowski jako autorów cytowanych wypowiedzi podaje w notach 1, 2 i 3 do powyższego cytatu: H. Manna, t. 1 Essays, Berlin 1954, s. 120 n., A. Tate'a, Techinques of Fiction, w zbiorze Forms of Modern Fiction, Essays Collected in Honor of J.W. Beach, Minneapolis 1948, s. 37 i J. Cassou, Situation de l' art moderne, Paryż 1950, s. 20. Autor uznaje „zaćmienie” flaubertologów francuskich w kwestii analizy estetycznej, stwierdza, że na Zachodzie wierni Flaubertowi pozostali tylko Anglosasi. M. Żurowski, „Pani Bovary” i rozwój powieści nowoczesnej, „Przegląd Humanistyczny" 1958, nr 4 (7), s. 18. 
pisarzy europejskich i latynoamerykańskich do twórczego podjęcia literackiego wątku, ba, moralnej oceny historii wiarołomnej Emmy Bovary, żony francuskiego prowincjonalnego lekarza, która, marząc o wielkiej romantycznej miłości i życiu $\mathrm{w}$ arystokratycznym świecie, zdradzała go z mężczyznami trochę w istocie podobnymi do samego Flauberta. O edypalnej fascynacji Flauberta kobietami, które błądzą, wizytach pisarza u kobiet zamężnych, dziejach wielkiej cudzołożnicy Delphine Delamare i rodzinnej tragedii Eugène’a Delamare’a, wiejskiego lekarza, notorycznie zdradzanego przez kobietę "niereformowalnie nimfomańsko i dziko rozpustną", nota bene znajomą matki pisarza, traktuje książka Frederica Browna (Gustaw Flaubert w niewoli słowa i kobiet, 2008). W dziele tym Flaubert - socjopatyczny geniusz jawi się jako artysta pełen sprzeczności, oskarżony o niemoralność przez bezduszne mieszczaństwo, nie rozumiejące związku między uwodzeniem kobiet a doskonaleniem powieściowego stylu i zdobywaniem naturalistycznej biegłości w portretowaniu kobiecych i męskich namiętności. Zasadą twórczości Flauberta (która stanie się bliska Eçie i pisarzom Ameryki Łacińskiej) było „ośmieszanie mieszczańskich słów, gestów i nałogów"s, rzeczy i spraw, które były dla niego zmorą przez całe życie, związanych głównie z poczuciem „wydziedziczenia ze świata, w którym istnieje miłość”. Portugalia i Brazylia, zainspirowane twórczością francuskiego realizmu, wydały również piewców pozamałżeńskiej miłości, nienasycenia i tęsknoty. Katastrofa wiarołomnej kobiety nie przychodzi z zewnątrz, ale rodzi się w głowie pisarza - tak jak w umyśle Flauberta powstała Pani Bovary, inspirując portugalskich i brazylijskich pisarzy do przedstawienia mrocznej kobiecej duszy, nagminnie krzywdzonej przez purytańską opinię w Europie i Nowym Świecie. Pani Bovary, Kuzyn Bazyli i recepcja powieści w Brazylii obrazują proces twórczy pisarzy, migrację wątków recepcyjnych, specyfikę francusko-portugalskich i portugalsko-brazylijskich relacji kulturowych. Z recepcją łączą się pierwsze reakcje czytelników, recenzje i twórcze naśladownictwo w Portugalii i Brazylii. Bovaryzm staje się egzystencjalnym symbolem epoki, kobiecym sposobem bycia, śnienia na jawie, a także celnym uderzeniem w martwą konwencję, w hipokryzję i samozadowolenie. Dołącza się do wczesnomodernistycznych koncepcji z zakresu historii idei, walcząc ze zniewoleniem ciał i umysłów, bezmyślnością, zamętem i kołtunerią. Nikt, jak pisarze realizmu krajów romańskich nie pisał tak wnikliwie o zjawisku kojarzonym kiedyś z grzeszną, pozamałżeńską miłością, dziś z miłością „toksyczną” lub emocjonalnym i fizycznym uzależnieniem, fatalnym zauroczeniem czy takim fatalnym splotem okoliczności, w którym miłość nie daje szczęścia i spełnienia, ale prowadzi do wielorakich cierpień, a w konsekwencji do śmierci bohaterki.

4 F. Brown, Pani Bovary, w: Gustaw Flaubert w niewoli słowa i kobiet, przeł. L. Niedzielski, Twój Styl, Warszawa 2008, s. 364.

5 J. Parandowski, Przedmowa, w: G. Flaubert, Pani Bovary, przeł. A. Micińska, PIW, Warszawa 1957, s. 6.

6 Tamże, s. 17. 
Vladimir Nabokov (1899-1977), tłumacząc amerykańskim studentom, na czym polega bogactwo tematycznych wątków, stylu, poezji i postaci Madame Bovary (1857), wyjaśnia znaczenie, jakie słowu bourgoeois nadał Flaubert, używając terminu „filister” dla określenia „ludzi pochłoniętych głównie sprawami materialnymi i wierzącymi wyłącznie w konwencjonalne wartości"”. Zdaniem autora skandalizującej Lolity (1956) „burżuj u Flauberta to stan świadomości, nie portfela”, ponadto „Flaubert był człowiekiem wiodącym żywot zamożnego dżentelmena, Marks zaś filistrem w swoim stosunku do sztuki"8. Eça de Queirós, pisarz portugalskiego realizmu, połączy krytykę lizbońskiego mieszczaństwa z niezwykle wnikliwym, barwnym, niekiedy humorystycznym przedstawieniem tej warstwy społecznej, tworząc postacie-typy, które na stale zadomowią się w literaturze portugalskiej. Luiza de Mendonça jako portugalska pani Bovary będzie od swojej francuskiej poprzedniczki o wiele bardziej uczciwa, sentymentalna, czuła i bezbronna, a bezsens jej śmierci oburzy z pewnością czytelnika o gustach romantycznych, niezdającego sobie sprawy, że oto nadciąga wszechmocny realizm, obnażając dawne tematy i skrywane obsesje.

Ryszard Engelking (kolejny, po Anieli Micińskiej, tłumacz Pani Bovary, opatrzonej podtytułem: $Z$ obyczajów prowincji) pyta o rację dzieła Flauberta we współczesnym świecie i nie traci złudzeń, że dziewiętnastowieczną powieść może ożywić wyobraźnia czytelnika:

Oczywiście książkę Flauberta można również czytać w tramwaju i przed zaśnięciem, ale śpieszny, ociężały duchowo czytelnik nie odkryje jej uroków i sekretów. Stwierdzi zapewne, że Emma jest „całkiem jak żywa”, ale powieść toczy się zbyt wolno, brak w niej napięcia i niespodzianek, a bohaterowie są rozpaczliwie niemodni, gdyż powinni nosić T-shirty i dżinsy, uprawiać seks grupowy i z fasonem skakać z dwunastego piętra. Taki czytelnik uzna, że panowie w cylindrach i panie w krynolinach niewiele mają mu do powiedzenia. I chyba się jednak pomylił; jeśli lubi myśleć i ma trochę wyobraźni, powinien powtórzyć lekturę, jego wysiłek nie pójdzie na marne?.

Być może historia Emmy złożyła się z „obudzenia zmysłów” bohaterki i samowiedzy Flauberta - jak domniemywał Żurowski" ${ }^{10}$ łącząc pierwiastek żeński i męski, problemy moralności, estetyki i romantycznej rêverie. Francuski pisarz o rozedrganej romantycznej duszy bytującej w udręczonym przez epilepsję ciele pragnął stworzyć idealnie obiektywną prozę i w tym celu karmił się frenetycznie

7 V. Nabokov, Gustaw Flaubert (1821-1880) Pani Bovary (1856), w: Wykłady o literaturze, przeł. Z. Batko, Warszawa 2000, s. 186.

8 Tamże.

9 R. Engelking, Jak dziś czytać „Panią Bovary”, w: G. Flaubert, Pani Bovary. Z obyczajów prowincji, słowo/obraz terytoria, Gdańsk 2005, s. 342.

10 M. Żurowski, dz. cyt., s. 22. 
pożeranymi, nocnymi lekturami: Apulejusza, Moliera, Chateaubrianda, Dantego, Szekspira, Sofoklesa, Boileau, Stendhala, Balzaka, La Fontaine’a, Montaigne’a Bossueta, Hugo, Horacego, Homera, Goethego i Ronsarda" oraz nauką greki; syn i brat wybitnych lekarzy, trzymał książkę, słownik i pióro jak oni skalpel. Namiętne czytelnictwo, studia filologiczne i systematyczna praca pisarska miały zabić larwę „strasznego mieszczanina” i stworzyć dzieło życia Flauberta na gruzach romantycznego śnienia i fantazmatu „marzenia z romantycznych książek”, które Maria Janion opisała w artykule Kapelmistrz Kreisler i pani Bovary (zawartym w zbiorze Prace ofiarowane Henrykowi Markiewiczowi, 1984). Następnie należało obalić „jedyny słuszny” światopogląd (Flaubertowi i Eçie chodziło o romantyzm, Żurowskiemu oczywiście o marksizm, Janion o mistycyzm i fantastykę), wpłynąć na wyobraźnię i odnowić literaturę epoki zmierzchającego romantyzmu w myśl zasady realistycznego obiektywizmu i prekursorskiego naturalizmu.

George Sand wypominała Flaubertowi, iż Panią Bovary uznano za książkę niemoralną i powinien był on wyraźnie wypowiedzieć opinię na temat cudzołóstwa, którą posiadał sam - chodziło o dosadne potępienie rozwiązłości bohaterki, naiwności jej męża i nikczemności kochanków ${ }^{12}$. Zaś Maria Janion rozpoznała w Emmie Bovary ofiarę „romantycznych książek”, które „gotują swoim wyznawcom najgorsze nieszczęścia”; zdaniem badaczki, Emma uległa „samowampiryzacji” i umarła zażywszy „arszenik romantycznego marzenia”"13. Janion oskarża Flauberta o kicz ${ }^{14} \mathrm{i}$ otwarcie krytykuje romantyczną rêverie, bez której nie byłoby Emmy, Luizy i wielu, wielu innych zwolenniczek wolności. Bez „zbójeckiej” pani Bovary nie powstałyby tytaniczne bojowniczki o realizację kobiecych marzeń - bohaterki wielu powieści i feministycznych dyskursów. Słuszne natomiast wydaje się uchwycenie istoty bovaryzmu przez cytowaną badaczkę:

Romantyczne marzenia z romantycznych książek gotują swoim wyznawcom najgorsze nieszczęścia. Wśród nich - zdaniem Flauberta - najdotkliwszy staje się fałsz, kłamstwo, mistyfikacja. Figurą losu monstrualnie oszukanej przez marzenie Emmy Bovary staje się straszliwy żebrak, podążający za dyliżansem, którym udaje się ona do kochanka. Flaubert nie szczędzi naturalistycznych szczegółów: dwa krwawe oczodoły pośród czerwonych strzępów rozpadającego się ciała, sączy się z nich ciecz zastygająca zielonymi strupami aż na nosie. To on śpiewa stale wesołą piosenkę o marzeniu:

Niekiedy w upalne dni/O miłości dziewczę śni ${ }^{15}$.

11 F. Brown, dz. cyt., s. 376.

12 G. Sand, Listy do Flauberta, przeł. M. Dramińska-Joczowa, PIW, Warszawa 1958, s. 213. M. Janion, Kapelmistrz Kreisler i pani Bovary, w: Prace ofiarowane Henrykowi Markiewiczowi, red. T. Weiss, Wydawnictwo Literackie, Kraków 1984, s. 331. 
Flaubert dla większości badaczy pozostaje do dziś uczniem Balzaka, krytykiem „społeczeństwa zupełnie zużytego - gorzej niż zużytego: zdziczałego i żarłocznego - które czuje wstręt tylko do fikcji, a kocha tylko posiadanie"16. Nie ulega dziś wątpliwości, że „jego znakomitą książkę uczcili i uwieńczyli liczni artyści, pośród których znaleźli się ci najbardziej wyczuleni i obdarzeni największym zaufaniem"17 - także, a może i przede wszystkim w Portugalii i Brazylii, mitycznej krainie „nie z tego świata”, skąd do Europy przybywają żaglowce czy też karawele portugalskich odkryć geograficznych, ewokując już nie zazdrość z powodu kolonialnego dobrobytu, ale postkolonialną tęsknotę-nostalgię - saudade ${ }^{18}$ za ancien régime'em

16 Ch. Baudelaire, „Pani Bovary” Gustava Flauberta, w : Sztuka romantyzmu, komentarze i przypisy Claude Pichois, słowo/obraz-terytoria, Gdańsk 2003, s. 99.

17 Tamże.

18 Saudade - tęsknota-nostalgia, zbiorowa melancholia (przede wszystkim portugalska, ale także brazylijska i galisyjska), tęsknota za wielką imperialną i kolonialną przeszłością, określająca świadomość narodową i główną cechę charakterystyczną portugalskiej tożsamości. Pojęcie to, które należy dziś kojarzyć z historią idei, było obecne w kulturze Półwyspu Iberyjskiego od końca XIII w. (w liryce trubadurów galisyjsko-portugalskich). Zostało zdefiniowane przez króla D. Duarte w traktacie filozoficznym Leal Conselheiro (Lojalny Doradca), spisanym w roku śmierci portugalskiego monarchy (1438). Saudade rozumiana jest w nim jako cecha ludzkiego charakteru i może mieć związek z tęsknotą za ukochaną osobą, poczuciem straty i smutkiem przemijania, ale również z subtelną radością związaną ze wspominaniem przeszłości, równie szczęśliwej co teraźniejszość. Saudade i „o saudosismo” - filozofia saudade, kojarzona z jedyną prawdziwą filozofią portugalską (pieśniami fado i mitem zaginionego w bitwie pod Alcácer-Quibir w 1578 r. króla Sebastiana, czyli sebastianizmem) stała się pod koniec XIX w. podstawą prądu w literaturze zwanego Odrodzeniem Portugalskim, reprezentowanego przez młodego Fernanda Pessoę (1888-1935), najwybitniejszego pisarza portugalskiego XX w. W opracowaniu In Portugal (1912) A.F.G. Bell napisał: „The famous saudade of the Portuguese is a vague and constant desire for something that does not and probably cannot exist, for something other than the present, a turning towards the past or towards the future; not an active discontent of poignant sadness but an indolent dreaming wistfulness" (cyt. za: Emmons, Shirlee and Wilbur Watkins Lewis, Researching the Song: A Lexicon, Oxford University Press, Oxford, s. 402). W Polsce po raz pierwszy o saudade jako nieprzetłumaczalnym terminie definiującym „duszę portugalską” pisał Józef Dzierżykraj-Morawski omawiając literaturę portugalską w Wielkiej literaturze powszechnej, red. St. Lam, Evert i Michalski, Warszawa 1933, t. 2, cz. 2, s. 1032. Ewa Łukaszyk, wspominając eseje Eduardo Lourenço zawarte w Labirinto de Saudade. Psicanálise Mítica do Destino Português (1972), pomyślane jako projekt autognozy i zdefiniowania portugalskiej tożsamości narodowej oraz ruch zwany o saudosismo (chodzi o nacjonalistyczną portugalską filozofię saudade), dowodzony przez Teixeira de Pascoaes (1877-1952) jako lidera Odrodzenia Portugalskiego, stwierdza, iż saudade i o saudosismo to dla Portugalczyków nie tylko „duchowa krew narodu i stygmat nakładający się na zbawcze rany Chrystusa”, ale przede wszystkim „filozofia narodowa i religia”. E. Łukaszyk, Imperium i nostalgia. „Styl późny” w kulturze portugalskiej, DiG, Warszawa 2015, s. 116-118. Saudade jako bezproduktywny dla teraźniejszości i przyszłości passeizm podważyło wstąpienie Portugalii do Unii Europejskiej w 1986 r. 
i panowaniem takiego czy innego monarchy, pod którego berłem kobiety nie były zmuszone do pracy na równi z mężczyznami, mając czas i sposobność, aby oddawać się marzeniom, lekturom i wolnej, pozamałżeńskiej miłości.

\section{Eça de Queirós, czyli portugalskie dziedzictwo realistycznego pejzażu}

José Maria Eça de Queirós (Póvoa de Varzim, 25.11.1845 - Paryż, 16.08.1900), jeden z najwybitniejszych portugalskich pisarzy, zwany „portugalskim Balzakiem”, absolwent prawa na Uniwersytecie w Coimbra, podróżnik i dyplomata zatrudniony w portugalskich placówkach dyplomatycznych na Kubie, w Anglii i we Francji, „należy do najbardziej znanych i najczęściej tłumaczonych pisarzy portugalskich. Jego wpływ na pisarzy Portugalii i Brazylii oraz pisarzy języka hiszpańskiego po obu stronach Atlantyku był w końcu XIX i w początkach XX wieku bardzo duży"’9. Dzięki Wydawnictwu Literackiemu w Krakowie, serii wydawniczej Literatura Iberyjska i staraniom polskich tłumaczy (głównie małżeństwa Krystyny i Wojciecha Chabasińskich) opowiadanie Singularidades duma rapariga loira (1874, wydanie polskie Dziwactwa pewnej blondynki, w zbiorze: Opowiadania portugalskie XIX i XX w., 1978 oraz e-booki z serii Virtualo), jak również powieści Eça de Queirós tłumaczone na język polski, takie jak: O Primo Basílio (1878, Livraria Chardron w Porto, wydanie polskie Kuzyn Bazyli w tłumaczeniu Elżbiety Reis, z posłowiem Janiny Z. Klave, 1978), O Crime do padre Amaro (1875, wydanie polskie Zbrodnia księdza Amaro, Czytelnik 1951 i Ordeno, 2010), Os Maias (1888, wydanie polskie Ród Maia, 1988) wpisują się w historię relacji literackich i historycznych między polską a Portugalią w XIX i XX wieku. Przyczynek do tematu stanowi również korespondencja portugalskiego historyka Joaquima Pedro de Oliveira Martins (1845-1894) z Władysławem Mickiewiczem, synem poety Adama na temat zasadności przekładu na język francuski i upowszechnienia noweli fantastycznej Eçy pt. O Mandarim (Mandaryn, wydanie polskie opublikowane w 2001 r. $)^{20}$.

19 J. Klave, Historia literatury portugalskiej. Zarys, Ossolineum, Wrocław 1985, s. 247.

20 Por. A. Kalewska, A fortuna cultural do Prefácio a "O Mandarim" de eça de Queirós: a correspondência de Ladislao Mickiewicz e Oliveira Martins como factor de internacionalização de Eça, w: Congresso de Estudos Queriosianos IV Encontro Intternacional de Queirosianos Actas, org. C. Reis e inn., Instituto de Língua e Literatura Portuguesa, Faculdade de Letras da Universidade de Coimbra 6 a 8 de Setembro de 2000, Almedina, Coimbra 2002, vol. 1, s. 379-391. Do omawianego tematu wniesie na pewno wiele nowego książka Ewy Łukaszyk, zapowiedziana na koniec 2017 r. jako Literatura portugalska od romantyzmu do wspótczesności. Wykłady i interludia, Ossolineum: Wrocław, E. Łukaszyk, blog, książki, forthcoming: http://www.ewa-lukaszyk.com/ books.html [dostęp: 22.08.2017]. Dla ogólnej orientacji w rozwoju studiów portugalistycznych w Polsce polecamy: taż, Bibliografia anotada de contribuições em estudos portugueses e lusófonos, http://www.ewa-lukaszyk.com/bibliografia-de-estudos-portugueses.html [dostęp: 22.08.2017]. 


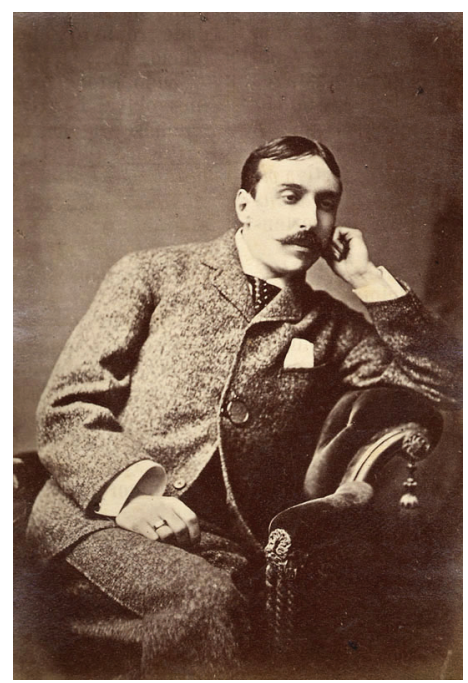

Fot. 1. Eça de Queirós w 1882 r., ilustracja w O Contemporâneo, Lizbona, nr 108/1882. Ze zbiorów Biblioteki Narodowej w Lizbonie

Przypominając, iż zamiarem (ba, „ideałem”) Eçy de Queirós było napisanie „historii naturalnej” społeczeństwa portugalskiego na wzór Balzaka, którego uważał za swojego mistrza na równi z Flaubertem, (powieść Kuzyn Bazyli była nazwana portugalską Panią Bovary) i stworzenie cyklu powieści czy studiów dających obraz rzeczywistości w Portugalii, Janina Z. Klave omawia dość dokładnie twórczość portugalskiego pisarza w Historii literatury portugalskiej, a nteresującej nas powieści poświęca passus pozwalający nam zorientować się w treści dzieła:

Kuzyn Bazyli przenosi nas do stolicy Portugalii, w środowisko drobnomieszczańskie. Banalna historia trójkąta małżeńskiego, zakończona śmiercią wiarołomnej żony, jest pretekstem do przedstawienia pewnej warstwy społecznej z jej zakłamaniem, brakiem zasad moralnych, lekkomyślnością, bezmyślnością i płytkością zainteresowań. Oto co pisze autor do przyjaciela, Teofila Bragi, w liście z 12 marca 1878 r.: „Mieszczaństwo w Lizbonie składa się z małymi odchyleniami z takich właśnie dominujących elementów. Znam przynajmniej dwadzieścia grup o podobnym układzie. Tak więc Kuzyn Bazyli daje mały obraz życia bardzo pospolitego: pani domu sentymentalna, źle wychowana, nie mająca wyższych zainteresowań ani nie religijna, to znaczy bez moralnych podstaw uczciwości, rozczytana w romansach, o temperamencie nadmiernie pobudliwym z powodu bezczynności, braku dyscypliny moralnej itd. - czyli typowa mieszczka. Z drugiej strony kochanek jest nicponiem nie mającym nic na usprawiedliwienie tyranii, jaką stosuje wobec Luizy, gdyż jej nie kocha, a tylko chce łatwej przygody powodowany próżnością. Z trze- 
ciej strony występuje służąca, buntująca się przeciw swojemu stanowi i łaknąca zemsty. Społeczeństwo otaczające te osoby nosi takie cechy, jak oficjalny formalizm (Acácio), głupia biogoteria (pani Felicidade), głupia literatura (Ernestinho) i zdarzający się rzadko porządny człowiek, jakim jest Sebastian. W powieści zaatakowana została rodzina mieszczańska, przedstawiona jako „przykre więzy sprzecznych egoizmów”. Problem nieudanego małżeństwa należał zresztą do stałych tematów realistów jak przejaw krytyki społecznej ${ }^{21}$.

Argumentacja i dobór cytatu stawiają Janinę Z. Klave wśród moralistycznych komentatorek kwestii „nieudanego małżeństwa” z ducha George Sand i Marii Janion, tak jakby agonia romantycznej marzycielki-samobójczyni mogła znaleźć zdroworozsądkowe wytłumaczenie. Mieszczaństwo, w ujęciu Flauberta prowincjonalne i okrutne, u Eçy jest bardziej eleganckie i oświecone, choć może niekiedy trochę zacofane i prowincjonalne, być może nawet dobrotliwe (w osobie Sebastiana, przyjaciela rodziny); Luiza kocha swego męża Jorge'go i umiera najprawdopodobniej z powodu wyrzutów sumienia (a być może choroby, szaleństwa i wcielenia się w postać bohaterki Fausta ${ }^{22}$ czy też tragifarsy Ernestinha Honra e Paixão), choć on sam skłonny jest jej zdradę małżeńską przebaczyć. Eça wpisuje się w proces „dziedziczenia” realistycznego pejzażu w literaturze, zdiagnozowany i opisany przez Renatę Lis, plasując się w towarzystwie nie tylko Balzaka, Flauberta i Maupassanta, ale również Tołstoja, Turgieniewa, Hiszpanów i Latynosów, być może nawet kilku pisarzy z kraju „gryki jak śnieg białej”23, obrońców domu i miejsca w nim kobiety, a także demokracji i moralności. Kobiety, która naczytała się powieści Waltera Scotta i Dumasa, nasłuchała oper Gunoda i Donizettiego i chciała być choć trochę podobna do fikcyjnych bohaterek z romantycznych clichées. Pomyliła w końcu fikcję z rzeczywistością, i na tym polegał jej błąd, czyli złudzenie bovaryzmu.

W cytowanej wyżej monografii, jak również w Posłowiu do polskiego wydania Kuzyna Bazylego, Janina Z. Klave stwierdza, iż Eça de Queirós „w literaturze

21 J. Klave, Historia..., dz. cyt., s. 248-249.

22 Oto scena w teatrze São Carlos: „Faust i Małgorzata, spleceni w uścisku, omdlewający prawie, zamierającymi głosami śpiewali swój duet; melodia rozbrzmiewała delikatną i nowoczesną zmysłowością, tenor z zamglonymi oczyma, łapiąc się za pierś, lubieżnie ruszał biodrami i brał wysokie tony odcinając się od powolnych dźwięków skrzypiec, śpiew płynął hen, ku gwiazdom... Al pallido chiarore/ Deis astri d' oro... Luzie serce zabiło mocniej; ujrzała się siedzącą na kanapie w swoim salonie, wstrząśniętą popełnionym właśnie cudzołóstwem, i Bazylego z cygarem w kąciku ust, wystukującego z roztargnieniem tę samą arię - Al pallido chiarore dei astri d’oro. Całe jej nieszczęście zaczęło się tego wieczoru!" E. de Queirós, Kuzyn Bazyli, Wydawnictwo Literackie, Kraków 1978, s. 340-341.

R. Lis, dz. cyt., s. 239. 
światowej znany jest dzięki tłumaczeniom na czternaście języków"24, a jego wpływ na pisarzy hispano- i luzofońskich był bardzo duży, materializując się w formie literackich pomników i dziennikarskich epitafiów. Omawia następnie twórczość portugalskiego pisarza, jego podróże na Wschód, jego powieści i udział w zorganizowanych w maju $1871 \mathrm{r}$. prelekcjach, tzw. conferências democráticas no casino lisbonense, gdzie Eça wygłosił czwarty z kolei odczyt pod tytułem O realismo como nova expressão da arte (Realizm jako nowy wyraz sztuki). Opierając swój program odnowy literackiej na poglądach Taine’a i Produhona, konkretnie wyjaśnił, na przykładzie Pani Bovary Flauberta, na czym polega realizm w literaturze: realizm jest zdaniem Eçy „anatomią charakteru i fotografią ducha” (o realismo é a anatomia do carácter e a fotografia do espírito); zdanie to powtarzają wszystkie portugalskie podręczniki literatury, nie należy się więc dziwić, że Profesor Klave je opuściła.

Zrozumienie różnicy między soczystym, naturalistycznym, psychologicznie bardzo wiarygodnym Balzakiem a Eçą jako

typowym przedstawicielem portugalskiego intelektualisty wraz z jego subtelnym poczuciem humoru i drwiącym stosunkiem do życia i rzeczywistości, [którego] jednocześnie cechuje pewna melancholijna pogoda oraz ukrywany, jakby mimowolnie odczuwalny, sentyment czy nawet czułość w stosunku do tradycji Portugalii [...], jak również podstawowych wartości narodowych tkwiących w ludziach, w historii, w niepowtarzalnym krajobrazie kraju ${ }^{25}$

pozwala zdać sobie sprawę ze specyfiki bovaryzmu we Francji i Portugalii oraz w Brazylii. W Portugalii bowiem miałyby panować brandos costumes, czyli łagodne obyczaje, wobec czego namiętność musiałaby być mniej gwałtowna niż w Hiszpanii i Francji, czasem obleczona w kobiecy habit zakonny ${ }^{26}$ i poddawana nieustannie mechanizmom saudade, revêrie, marzenia-śnieniu, śnienia na jawie o miłości, pięknie i sprawiedliwości.

Jak powstawał Primo Basílio, czyli portugalska Pani Bovary? Chronologicznie, przypada na koniec niezwykle twórczego okresu pisarskiego Eçy jako portugalskiego konsula w Newcastle i Bristolu (w latach 1874-1878), jako że powieść ta została napisana podczas pobytu pisarza w Newcastle, a następnie opublikowana w Porto (1878). Ideowo, powieść zawdzięcza wiele Flaubertowi. Panią Bovary i Kuzyna Bazylego łączy wspólne mizoginiczne przekonanie o tym, że kobieta jako taka jest per-

24 J. Klave, Posłowie, w: E. de Queirós, Kuzyn Bazyli, przeł. E. Reis, Wydawnictwo Literackie, Kraków 1978, s. 399.

25 Tamże, s. 403.

26 Por. A. Kalewska, Bettina von Arnim, Rilke i Mariana Alcoforado - o pozorności kobiecego dyskursu powieściowego, „Studia Niemcoznawcze” 2015, vol. 16, s. 295-309. 
wersyjna i skłonna do cudzołóstwa, o czym należy przestrzec czytelnika (a zwłaszcza czytelniczkę!) w powieści, ukazując mu całą prawdę i grozę zjawiska, licząc na jej/jego poprawę obyczajów po akcie lektury. W sensie strukturalnym tekst portugalski powstawał bardzo podobnie, jak francuski pierwowzór, czyli na zasadzie rozbudowania opowiadania-narracyjnego embrionu i umoralniającej powiastki.

Jakie były zatem narracyjne początki Pani Bovary i Kuzyna Bazylego? Frederic Brown nadmienia, że francuskiego pisarza zawsze interesowała wszetecznica, która w Kuszeniu świętego Antoniego (1874; wydanie polskie w przekładzie Piotra Śniedziewskiego 2010) delektuje się „grą skrywanej wiarołomności”"27. Flaubert naszkicował pierwsze zarysy historii Emmy w opowiadaniu zatytułowanym $\mathrm{Na}$ miętność a cnota: powiastka filozoficzna. Mówi Brown:

Jego [Flauberta] bohaterami są niewierna żona nazwana Mazza Willer, mąż bankier z przyprawionymi przez nią rogami oraz Ernest, zimny drań, który ją uwodzi i porzuca. Pierwowzorami dla całej trójki byli ludzie wplątani w straszliwy dramat, o którym pełny reportaż zamieściła Gazette des Tribunaux z 4 października 1837 roku. W opowiadaniu Gustawa ich historia jest ilustracją łatwości, z jaką pożądanie przekształca zwykłą mieszczkę w nieokiełznaną kobietę gardzącą wszelkimi moralnymi hamulcami. „Nieograniczoność” jest jego określeniem odnoszącym się zarówno do niebios, jak i do piekła sofistycznej namiętności, w której Mazza zatraca się po wyzwoleniu ze społecznych ograniczeń. [...]. Wszystko, co upadła Mazza potrafi stwierdzić, to tylko upajający charakter występku. Jej potrzeby są tak żarłoczne, że Ernest szuka ucieczki w Ameryce. Obarczona mężem i dwojgiem dzieci, Mazza truje ich. Kiedy jednak kochanek, z którym ma nadzieję połączyć się na nowo, informuje ją o swym rychłym ślubie z majętną młodą Amerykanką, Mazza kieruje swą wściekłość ku sobie i wypija kwas pruski. [...] Kobieta cudzołożna jest „bardziej kobietą" niż jej potulna siostra, oznajmia Flaubert ${ }^{28}$.

Eça de Queirós uznaje postulaty Proudhona, czyta Balzaka, Flauberta i Zolę i publikuje utwory, których tematem jest zjawisko określone przez współczesną amerykańską badaczkę Robin Norwood jako toksyczna miłość, występująca u kobiet, które w wyniku niedostatków emocjonalnych w dzieciństwie jako osoby dorosłe „kochają za bardzo” mężczyzn, z którymi nie mogą być szczęśliwe, starając się znaleźć miłość, której wcześniej nie otrzymały ${ }^{29}$. Wzorzec love hurts realizują: inicjujące portugalski realizm, wspomniane wcześniej opowiadanie Singularidades de uma rapariga loura (Dziwactwa pewnej blondynki, 1874), opublikowane na łamach

27 F. Brown, dz. cyt., s. 363.

28 Tamże, s. 363-364.

29 Korzystałam z wydania portugalskiego: Robin Norwood, Mulheres que amam de mais, Porto Editora, Porto 2011. 
O Brinde aos Assinantes do Diário de Notícias, powieści O Crime do Padre Amaro (Zbrodnia księdza Amaro, 1875), O Primo Basílio (Kuzyn Bazyli, 1878), A Relíquia (Relikwia, 1887), a także wariant narracyjny „portugalskiej Madame Bovary”, opowiadanie No Moinho (W młynie).

Opowiadanie $W$ młynie zostało opublikowane po raz pierwszy na łamach prasy literackiej (w czasopiśmie O Atlântico) w kwietniu 1880 r., a następnie w pośmiertnym zbiorze opowiadań Eçy (Contos, Livraria Chardron de Lello e Irmão, Porto 1902). Utwór ten zdradza zaawansowane cechy realizmu psychologicznego i początki naturalistycznego, fizjologicznego opisu dziedzicznych upośledzeń i ułomności kobiecej natury. Maria de Piedade, bohaterka opowiadania $W m \not y$ nie, ciemnooka blondynka skromnie ubrana na czarno, mieszka na wsi i opiekuje się chorym mężem i dwójką niedomagających dzieci. Miała trudne dzieciństwo: uzależnionego od hazardu i alkoholu ojca i sadystyczną matkę. Wyszła za mąż za lekarza, aby uciec z domu, bez miłości, aby ratować wystawiony na licytację dom rodziców. Żyła cicho i skromnie. A jednak, w którymś momencie, mówi Eça, „a Santa tornava-se Vénus”30, czyli „święta stała się boginią miłości”. Dobra i przykładna żona, matka rodziny, czytająca mężowi Żywoty świętych pożera czytelniczo powieści i wiersze zmierzchającego romantyzmu, które sieją w jej głowie zamęt i moralne spustoszenie. Jak ojciec Marii de Piedade oddawał się kiedyś pijaństwu i miłostkom, tak ona sama - w myśl naturalistycznego przekonania o dziedziczeniu mentalnych i cielesnych upośledzeń - zaczyna znajdować upodobanie w egzaltowanych lekturach i cudzołożnej miłości. A to dlatego, że do wsi, w której mieszka bohaterka, przybywa w celu sprzedaży nieruchomości kuzyn Adrian, daleki krewny jej męża (narracyjny prototyp kuzyna Bazylego), znawca kobiet i literatury, brylujący w Lizbonie powieściopisarz. Adrian odnajduje swą wiarołomną Magdalenę-upadłego kobiecego anioła (Magdalena - taki tytuł nosiła powieść napisana przez kuzyna Adriana) i cynicznie ją uwodzi, na łonie zdegradowanej, posępnej i nieprzyjaznej natury, a następnie, jak się wydaje, w opuszczonym starym młynie ją posiada i niecnie porzuca, zadowolony z tego, co dostał:

E de repente, sem que ela resistisse, prendeu-a nos braços, e bejou-a sobre os lábios, de um só beijo profundo e interminável. Ela tinha ficado contra o seu peito, branca, como morta: e duas lágrimas corriam-lhe ao comprido da face. Era assim tão dolorsa e fraca, que ele soltou-a; ela ergue-se, apanhou o guarda-solinho, e ficou diante dele, com o beicinho a tremer, murmurando: - é mal feito... é mal feito... [...]. Mas no fundo estava contente da sua generosidade ${ }^{31}$,

30 E. de Queirós, No Moinho, w: H. M. Almeida Gonçalves, M. da Assunção Monteiro, Introdução à leitura de contos de Eça de Queirós, Almedina, Coimbra 2001, s. 152.

31 „I nagle, nie czując z jej strony oporu, schwycił ją w ramiona i pocałował w usta, głębokim i namiętnym pocałunkiem. Blada, nieomal umarła, oparła się o jego pierś i dwie łzy spłynęły 
aby ostatni raz ją w tytułowym młynie pocałować i odjechać po krótkim pożegnaniu do Lizbony. Jak zawsze u Eçy, akt cudzołóstwa upokarza kobietę i jest przygotowany przez opis posępnego miejsca schadzki, współgrający w estetycznej tonacji z moralną mis-en-abime Marii/Luizy/Amelii, czyli bohaterek opowiadania W mlynie i powieści Kuzyn Bazyli oraz Zbrodnia księdza Amaro. A jednak Eça nie będzie plagiatorem ani ślepym naśladowcą Flauberta jako autora Madame Bovary, ani Emila Zoli i jego Faute de l'Abbé Mouret. W przeciwieństwie do Borgesowskiego Pierre'a Menarda, autora Don Kichota nigdy nie odrzuci swobody literackiej kreacji, opisów realiów Lizbony i portugalskiej prowincji nie podda bezwarunkowo dyscyplinie „szkiełka i oka”, a literacki obraz metropolii nad Tagiem i jej transatlantyckie rubieże rozświetli twórczą wyobraźnią i wprowadzi doń kolorowy, psychologicznie prawdopodobny, a czasem i rozśpiewany, roztańczony i egzotyczny korowód kobiecych i męskich postaci.

Maria da Piedade zakochała się jednak w Adrianie, odwiedzała go, gdy zamieszkał w opuszczonym młynie, czytała jego książki utrzymane w późnoromantycznej, sentymentalnej stylistyce i pragnęła być jedną z jego wyimaginowanych bohaterek, aby - jak słusznie pisała Maria Janion o romantycznych heroinach - „dać się obłąkać marzeniu” i doprowadzić swą rodzinę do upadku. Wszystko przez „książki zbójeckie”, oryginały lub lokalne imitacje Łucji z Lamermoo$r u$ i powieści Waltera Scotta, albo i sentymentalnie a naiwnie pojętego Geniusza chrześcijaństwa i uczuciowych Męczenników rodem z Chateaubrianda. W takich i podobnych im lekturach gustowały bowiem Emma, Luiza i inne bohaterki bovarystycznych intryg i romansów. Romantyczna z natury, a zarazem realistycznie sportretowana bohaterka wpada w histerię (zapowiadającą stany Luizy po odjeździe Basília), zaczyna nienawidzić męża i rodzinę i jako ofiara „chorego romantyzmu" (o romanticismo mórbido), następnie zaś rzuca się w ramiona pierwszego lepszego pretendenta, praktykanta w aptece. Zostawia dom, dzieci i męża i podąża za leciwym aptekarzem, aby finansować jego kochankę i stać się we wsi pośmiewiskiem. Umiera dla świata i społeczeństwa.

W mlynie Eça przedstawia zatem kobiece cudzołóstwo w wiejskiej, romantycznej scenerii, zgoła inaczej, niż w Kuzynie Bazylim, gdzie tło uczuciowych potyczek stanowią domy, ulice, teatry i tajemne zaułki Lizbony. Prowincjonalna bohaterka krótkiego romansu przeistoczyła się w lizbońską mieszczkę, z jednakowym wszak skutkiem: zniszczeniem miejscowego ładu społecznego i rodziny oraz tragiczną degradacją osoby bohaterki. „Rajem” nazywa Adrian młyn jako miejsce schadzek, w podrzędnym hoteliku o tej samej nazwie miały miejsce spotkania Luizy i Basília. Bohaterki są do siebie fizycznie podobne, jednakowo scharakteryzowane przez narratora

jej po twarzy. Była tak słaba i zbolała, że on w końcu ją wypuścił; podniosła się, schwyciła parasoleczkę i stanęła przed nim, z drżącymi ustami, szepcząc: - to nie tak, to nie tak... W głębi duszy jednak była zadowolona z jego hojności". Tamże, s. 149-150 (przekł. mój, A.K.). 
jako dobre żony, skorumpowane wszak moralnie przez nieodpowiednie lektury i cynicznych kochanków. Tezą bronioną przez Eçę byłoby zatem przekonanie, że cudzołóstwo kobiety powodują przede wszystkim lektury romantycznych powieści ${ }^{32}$, jak również genetyczna, odziedziczona po przodkach skłonność do patologicznych postępków. Sprawa wydaje się jednak bardziej skomplikowana, tym bardziej, że W mlynie jest tekstem późniejszym od Kuzyna Bazylego, zwieńczeniem tezy o podatności kobiety na cudzołóstwo, niezależnie od meio-ambiente (środowiska), w którym przebywa, wykształcenia, religijnego i moralnego skrupułu. Bovaryzm w Portugalii i Brazylii będzie tej tezy wyraźnym przykładem; powieści latynoamerykańskie i europejskie o kolejnych, często pozamałżeńskich związkach i sposobach egzystowania kobiety w społeczeństwie dostarczą większej ilości rozwiązań narracyjnych, dowodząc niekiedy możliwości absolucji bohaterki i jej społecznej reintegracji ${ }^{33}$.

Madame Bovary (1857) i O Primo Basílio (1878), podobnie jak Anna Karenina (1875-1877) Tołstoja i La Regenta (1884-1885) Leopolda Alasa ${ }^{34}$, Giacinta (1879) Luigi Capuana, L' Adultera (1882) i Effi Briest (1895) Theodora Fontanego czy Summer Before the Dark (1973, Lato przed zmierzchem, Czytelnik 1976) Dorris Lessing należą do klasyków literatury światowej. Powieściom realizmu i społecznego postępu - Dom Casmurro (1899) Machada de Assis (choć spotykamy tu raczej dramat męskiej zazdrości niż kobiecego cudzołóstwa), podobnie jak powieści o brazylijskiej emancypantce, São Bernardo (1934) Graciliana Ramos - należy się miano oryginalnych i postępowych społecznie narracji, wyemancypowanych już od europejskiego dziedzictwa oraz krępującej formy à la Flaubert et Eça de Queirós.

\section{Bovaryzm w Portugalii i Brazylii, czyli luzofońskie metamorfozy Emmy Bovary}

Eça de Queirós, podobnie jak Gustaw Flaubert, oburzał się przez całe życie „na głupotę, ignorancję, komunały, dogmaty, religijne maskarady"35. Mechanizm, ostrze krytyki, tematy realizmu francuskiego i portugalskiego są bardzo podobne,

32 H.M. Almeida Gonçalves, M. da Assunção Monteiro, Introdução à leitura de Contos de Eça de Queirós, tamże, s. 140.

33 Moraes Rita Mara Netto de, A condição feminina no matrimônio, delineada pela ficção. Tese submetida ao Curso de Pós-Graduação em Literatura da Universidade Federal de Santa Catarina para a obtenção do grau de Doutora em Literatura. Orientadora: Profa. Dra. Odília Carreirão Ortiga, Universidade de Santa Catarina, Florianópolis 2009, ms, https://repositorio.ufsc.br/ bitstream/handle/123456789/92469/281158.pdf?sequence=1 [dostęp: 23.08.2017].

34 Leopoldo García-Alas Ureña (znany jako Clarín) w swojej powieści La Regenta (1884-1885) - realizacji bovaryzmu hiszpańskiego - inspirował się Flaubertem i Eçą de Queirós, z którego zdaniem niektórych krytyków miałby dokonać w sporych fragmentach plagiatu, cyt. za: Moraes, tamże, s. 45.

R. Lis, dz. cyt., s. 281. 
choć rysy cudzołożnych bohaterek nieco odmienne: Emma Bovary i Luiza Mendonça czytają romantyczne powieści (Emma także historyczne i filozoficzne), co w przypadku portugalskiej bohaterki, którą Vargas Llosa nazwał „tragiczną feministką", miało przyczynić się do kryzysu małżeńskiego ${ }^{36}$. Umierają na końcu: Emma-samobójczyni zażywszy arszenik, Luiza z poczucia wiarołomstwa, a może i pomieszania zmysłów (co sugeruje brazylijska wersja filmowa ${ }^{37}$ ). Feminizm tragiczny ma wiele wspólnego $z$ domową tragedią, rodzinnym dramatem, rozpadem małżeńskiego stadła, pytaniem o kondycję społeczeństwa w metropolii i byłej portugalskiej kolonii, któremu Eça i Machado nie szczędzili krytyki w swych powieściach i wypowiedziach dyskursywnych, choć dla nas ciekawszy wydaje się cień białego żaglowca płynący do Nowego Świata, dostrzeżony w wizyjnej wyobraźni Renaty Lis. Płynęli nim mężczyźni i kobiety poddani namiętnościom starym jak świat. Emma, Luiza i inne bohaterki powieści o kobiecym nieposłuszeństwie realizują mit Pazyfae, ogarniętej żądzą kreteńskiej królowej, zakochanej w świętym byku, podarowanym Minosowi przez Posejdona, który rzucił na nią klątwę, matki Minotaura i matki chrzestnej nowożytnego bovaryzmu.

Jak Madame Bovary lub mit o kobiecym nieposłuszeństwie został przyjęty w Portugalii i Brazylii, dlaczego francuską powieścią zainteresował się Eça de Queirós i młodzi pisarze brazylijskiego realizmu?

Jak dość już powszechnie wiadomo, reakcja literackiej krytyki i publiczności na Madame Bovary, publikowaną w odcinkach jesienią 1856 r. w Revue de Paris, a rok później w formie książkowej, nie była specjalnie przyjazna. „Redakcję niepokoiły przede wszystkim realistyczne sceny i szczegóły opisane w powieści Flauberta”38. Flauberta postawiono pod sąd, jednak dzięki zręczności mecenasa Sénard zarzuty prokuratora Ernesta Pinarda zostały oddalone, a werdykt uniewinniający ogłosiła Gazette des Tribunaux 9 lutego $1857 \mathrm{roku}^{39}$. Czytelników zaintrygował wszak powód oskarżeń: szokujący realizm w przedstawieniu ludzkich charakterów, jako że literatura percypowana była wówczas jako lekcja i umoralniająca egzemplifikacja cnoty. Naturalizm znalazł jednak szybko teoretyków i naśladowców we Francji w osobach Juliusza i Edmunda Goncourtów oraz Zoli (powieść Thérèse Raquin,

36 Cyt. za: Moraes, dz. cyt., s. 58-59.

37 Brazylijska ekranizacja Kuzyna Bazylego, film pt. Primo Basílio z 2007 r. (reż. Daniel Filho, COR) rozgrywa się w 1958 r. w São Paulo, adaptując powieść do warunków brazylijskich; kuzyn Bazyli przybywa z Europy, Jorge Mendonça (mąż Luizy) uczestniczy w budowie Brasílii, szczegóły obyczajowe dostosowane są do warunków lokalnych. Służąca Juliana zostaje skrytobójczo zamordowana przez przyjaciela rodziny (Sebastian), Luiza zwierza się powiernicy-Murzynce i popada w obłęd; śmierć bohaterki poprzedzona erotycznymi marzeniami-wspomnieniami nosi znamiona psychotycznej tragedii. https://www.youtube.com/watch?v=O3hUTt1Cupk [dostęp 24.08.2016].

38 Tamże, s. 183.

39 Tamże, s. 186. 
1867). Bez Gustawa Flauberta nie byłoby we Francji Marcela Prousta ani Jamesa Joyce’a w Irlandii i Eçy de Queirós w Portugalii. Niewątpliwą zasługą tego pisarza było wprowadzenie modelu powieści Flaubertowskiej w Portugalii o dekadę wcześniej, niż stało się to w większości krajów europejskich.

Tak jak dwadzieścia dwa lata wcześniej Madame Bovary, Kuzyn Bazyli wywołał skandal w 1878 r. w Portugalii i Brazylii, Lizbona i Rio de Janeiro nie od razu zachwyciły się powieścią z tezą o kobiecym cudzołóstwie. Co prawda Eça de Queirós nie został pozwany do sądu, jednak prasa literacka wytykała autorowi brak zdecydowanego potępienia postępowania Luizy, jak również „nadmiar odrażającego realizmu” w opisie („a superabundância de repugnante realismo”) ${ }^{40}$, kojarząc nowy prąd literacki najpewniej z sensualizmem i erotycznymi smaczkami powieści, o wiele wszak łagodniejszymi niż u Flauberta, oraz krytyką tradycyjnej mieszczańskiej rodziny. Jednakże, publiczność literacka w Portugalii wydawała się lepiej przygotowana od brazylijskiej do przyjęcia Kuzyna Bazylego. Po drugiej stronie Atlantyku ferowano o wiele sroższe oskarżenia o korupcję moralną (równą jakoby dekadencji w sądach i gospodarce). Jedynie Ramalho Ortigão, przyjaciel Eçy i rzecznik realizmu, bronił powieści, a zwłaszcza prawdopodobieństwa opisu Luizy, stylu i bezstronności narratora w pierwszej recenzji powieści, opublikowanej 25 marca 1878 r. w Brazylii na łamach Gazeta de Notícias ${ }^{41}$. Brazylijczyk Machado de Assis tęsknił za romantyzmem i jak wielu jego rodaków kojarzył termin naturalizm z domniemanymi brakami moralności Kuzyna i oczywistą demoralizacją Luizy.

Co na to Eça? Realizując zasady bezstronnej, bezosobowej narracji powieściowej zaobserwowanej u Madame Bovary Flauberta, nie mógł sobie pozwolić na skrytykowanie swojej bohaterki. Szacunek dla francuskiego autora, jak i niezależność myślowa oraz liberalizm Eçy nie nakłaniały autora Kuzyna Bazylego do sformułowania explicite tego, czego domagała się w Portugalii i w Brazylii publiczność literacka: krytyki i moralnego potępienia cudzołożnicy. Nowością było przestawienie jej dziejów - u obu pisarzy symultaniczne, filmowe, zawsze obiektywne, bez odautorskich komentarzy czy narracyjnego dialogu z czytelnikiem (lub czytelniczką, w czym w Portugalii folgował sobie czytany masowo i lubiany pisarz epoki poprzedniej, Camilo Castelo Branco, nota bene osadzony za... cudzołóstwo w Cadeia da Relação do Porto od 1.10.1860 do 17.10.1861). Poza tym Eça, podobnie jak Clarín, autor znacznie późniejszej La Regenta (1884-1885) mógł posiadać znajomość kobiecej seksualności i nie odmawiał Baudelaire’owskiej, poszukującej ideału i nowych doznań „samicy” prawa do przyjemności. Wypada dziś zanegować nieuzasadnione oceny

40 Cyt. za: A.A. Lourenço António Apolinário, De "Madame Bovary" ao "Primo Basílio": a singularidade bovarista de Luísa. "Letras de Hoje" 2012, Porto Alegre (Brasil), 47 (4), s. 416, n. 6. http:// revistaseletronicas.pucrs.br/ojs/index.php/fale/article/view/12776 [dostęp 24.08.2017].

41 Tamże, s. 416. 
„rodem z zakrystii”, którym pisarze tacy jak Flaubert, Tołstoj, Eça, Clarín czy Fontane bywali poddawani. I za Machado de Assis zgodzić się można, że „Luiza nie ma wyrzutów sumienia, [ona] się boi” ("Luísa não tem remorsos, tem medo”)"2 , boi jedynie męża i skandalu, a może i wysłania do klasztoru. Bowiem w przeciwieństwie do religijnej Emmy - która umierając „wyciągnęła szyję jak ktoś bardzo spragniony i przywarłszy wargami do Boga-człowieka złożyła na nim z całej siły swej konającej duszy najżarliwszy miłosny pocałunek, jaki dała kiedykolwiek"³ - portugalska bohaterka posiadała religijność raczej powierzchowną. Czytała niewiele chyba poza dawnymi harlequinami... Gdy dramaturg Ernestinho chciał opowiedzieć przypadkowo spotkanej Luizie o słynnym romantycznym dramacie Almeidy Garretta Brat Luís de Sousa (Frei Luís de Sousa, 1843), zajęta przygotowaniami do schadzki z Bazylim odparła, że nie ma czasu, bo musi iść do dentysty ${ }^{44}$. A może bała się, że sama stanie się wiarołomną Madaleną de Vilhena?

Już znacznie wcześniej, we wspominanym odczycie w kasynie lizbońskim w 1871 r. Eça wyraził zainteresowanie tematem cudzołóstwa, przedstawionego w formie „anatomicznej”, rozłożonego na czynniki pierwsze skalpelem pisarza tak, że w końcu objawił się realizm w literaturze, z zamiarem obrony moralności, sprawiedliwości i prawdy („é assim que se manifesta o realismo na arte [...] pelo tal intuito de moral, de justiça e da verdade" ${ }^{\text {"45 }}$ ). Eça, choć nadal pozostanie idealistą, nabierze Zolowskiego przekonania o tym, że światy fikcji są pasożytem świata realnego („os mundos ficcionais são parasitas do mundo real"46) i zapragnie stworzyć realistyczną powieść o cudzołóstwie na wzór Flauberta, adaptując do prozy portugalskiej jej główne zdobycze narracyjne: obiektywną, choć psychologicznie nacechowaną narrację (długo przed tym, gdy Roland Barthes ogłosi „śmierć autora”), mowę pozornie zależną, dokładne, obiektywne przedstawienie postaci i dyskretne użycie dialogu, zarezerwowanego dla momentów wyjątkowych. Zacytujmy zakończenie Emmy Bovary i Kuzyna Bazylego, gdy oszukani mężowie dowiadują się o zdradzie żony na podstawie znalezionych listów. I tak prostolinijny i nieco szorstki mąż Emmy Bovary

Przez szacunek czy też przez rodzaj zmysłowości, która kazała mu przewlekać poszukiwania, Karol nie otworzył jeszcze skrytki w palisandrowym biurku Emmy. Pewnego dnia wreszcie usiadł przy nim, obrócił klucz i nacisnął sprężynę. Były tam wszystkie listy Leona. Tym razem nie mógł mieć wątpliwości! Pochłonął wszystkie do ostatniego, przeszukał wszystkie kąty, wszystkie meble, wszystkie szuflady, rycząc, nieprzytomny, oszalały. Znalazł jakieś pudełko, rozbił je kopnięciem. Portret

\footnotetext{
42 Cyt. za: tamże, s. 419.

43 G. Flaubert, Pani Bovary, dz. cyt., tłum. A. Micińska, s. 379.

44 E. de Queirós, Kuzyn Bazyli..., s. 205.

45 Cyt. za: Lourenço, dz. cyt., s. 414.

46 Tamże.
} 
Rudolfa wyskoczył mu prosto w twarz spomiędzy porozrzucanych liścików miłosnych. [...] Któregoś dnia, gdy wybrał się na jarmark do Argueil, aby sprzedać konia - ostatni ratunek - Karol spotkał Rudolfa. [...].

- Nie mam do pana żalu - rzekł.

Rudolf zaniemówił. A Karol, z głową w dłoniach, powtórzył zgaszonym głosem, $\mathrm{z}$ rezygnacja bezmiernej boleści:

- Nie, nie mam już do pana żalu!

I dodał nawet wielkie słowo, jedyne wielkie słowo, jakie kiedykolwiek powiedział:

- Tak chciało przeznaczenie!

Rudolf, który pokierował owym przeznaczeniem, uznał go za nazbyt dobrodusznego jak na człowieka w jego położeniu, śmiesznego nawet i trochę nikczemnego ${ }^{47}$.

Inżynier Jorge Mendonça natomiast, przeczytawszy list kuzyna Bazylego do Luizy, wspominający „rozkoszne ranki”48 w podrzędnym hotelu Raj, rozwija bolesny monolog wewnętrzny (ujęty w karby mowy pozornie zależnej) i myszkuje $\mathrm{w}$ garderobie umierającej:

Pewnej nocy, z ostrożnością złodzieja, przeszukał wszystkie jej szuflady, przejrzał suknie, nawet poukładaną bieliznę, pudełko z biżuterią, z koronkami; zajrzał do skrzyneczki z sandałowego drzewa: była pusta, nawet szczątka zasuszonego kwiatka! Czasem spoglądał na meble w sypialni, w salonie, przyglądając im się tak, jakby mogły zachować ślady cudzołóstwa. Czy tu siadywali? A on klęczał przed nią, ot tam, na dywanie. Szczególnie szeroka, wygodna kanapa doprowadzała go do rozpaczy, znienawidził ją. Zaczął nie cierpieć domu, tak jakby dach, który go nakrywał, mury, które go podtrzymywały, były ze sobą w zmowie. Ale najbardziej torturowały go słowa „Raj”, „rozkoszne poranki”"49.

Powieść Eçy jest bardzo zbliżona do Madame Bovary, zdradzając bardzo wyraźne podobieństwo tematu, jak wewnętrznej struktury i wątków, sekwencji narracyjnych (mouvements, w terminologii Flauberta), stylu i charakteru postaci, czy też oddania atmosfery i ducha swojego $\mathrm{czasu}^{50}$.

47 G. Flaubert, Pani Bovary, dz. cyt., tłum. A. Micińska, s. 404-405.

48 E. de Queirós, Kuzyn Bazyli..., s. 363.

49 Tamże, s. 368.

50 Por. V. Nabokov, dz. cyt., s. 185. 


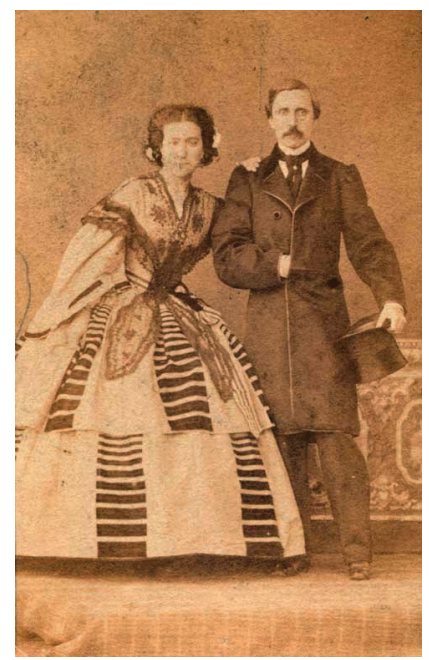

Fot. 2. Carolina Augusta Pereira de Eça de Queirós (1826-1918) i José Maria de Almeida Teixeira de Queirós (1820-1901) - rodzice Eçy de Queirós. Ze zbiorów Biblioteki Narodowej w Lizbonie

Eça de Queirós naśladuje zatem Flauberta, wprowadza jednak otoczenie i realia typowo lizbońskie, jak również galerię postaci: kuzyna Bazylego, samej Luizy, Leopoldyny (przyjaciółki pani domu, o skłonnościach lesbijskich), pani Felicidade (postarzałej kokietki), radcy Acácia, last but not least mściwej służącej Juliany (która u Flauberta nazywała się Felicja i po śmierci Emmy uciekła zabrawszy jej suknie), którzy jako typy społeczne („tipos”) zostali scharakteryzowani jako wspaniali („magníficos”) w liście ojca pisarza, José Maria de Almeida Teixeira de Queirós, z 26 lutego 1878 (list ten poprzedza siedemnaste wydanie oryginału portugalskiej powieści). W liście tym znajdujemy istotne pytanie o to, dlaczego kochająca i przykładna, dobrze wychowana i wykształcona żona z łatwością oddała się obcemu przybyszowi? Być może posiadała jakieś ukryte wady, może odziedziczone złe skłonności (jak np. bohaterka opowiadania W Młynie), lub też - co list sugeruje - miała jakieś ciągoty wynikające $\mathrm{z}$ błędów w wykształceniu, jakie bez wątpienia posiadała Amelia, bohaterka Zbrodni księdza Amaro. Może istotnie śmierci portugalskiej bohaterki winne były „książki zbójeckie”? Pragnienie doświadczenia podróży, doznania gwałtownych emocji, przeżycia miłosnej przygody? Zazdrość o światowe życie kuzyna? Monolog wewnętrzny Luizy podważa jednak wartość jej umysłowego przygotowania do życia w świecie realnym:

Tak bardzo pragnęła zwiedzić kraje, które znała z romansów: Szkocję z jej spokojnymi jeziorami, Wenecję i jej pełne tragedii pałace, zawijać statkiem do zatok, u których piaszczystych brzegów morze zamiera, drgające i błyszczące, i z chatki 
rybaka o płaskim dachu, gdzie mieszkają Grazielle, spoglądać na niebieszczące się w oddali wyspy o dźwięcznych nazwach. I być w Paryżu. Przede wszystkim w Paryżu! Ale cóż z tego! Nigdy na pewno nie będzie podróżować; byli niezamożni, a poza tym Jerzy jest domatorem, typowym lizbończykiem ${ }^{51}$.

Marzenia o podróżach, o przekraczaniu granic znanego świata, o prawdziwej miłości... Dlatego właśnie, dla świata luzofońskiego Kuzyn Bazyli pełni podobną funkcję co Madame Bovary: służy rozumieniu nas samych, naszego świata, losu i kultury (o czym pięknie pisała Renata Lis), stając się tejże kultury, kultury języka portugalskiego, ważnym i kontynuowanym tekstem.

\section{Bibliografia}

Baudelaire Charles, „Pani Bovary” Gustava Flauberta, wyd. 2 zm. i uzup., w: Sztuka romantyczna, przekład i wstęp A. Kijowski, komentarz i przypisy C. Pichois, słowo/obraz terytoria, Gdańsk 2003, s. 95-105.

Brown Frederic, Pani Bovary, w: Gustaw Flaubert $w$ niewoli słowa i kobiet, przeł. L. Niedzielski, Twój Styl, Warszawa 2008, s. 363-369.

Ceia Carlos, E-Dicionário de Termos Literários, http://edtl.fcsh.unl.pt/author/cceia/ [dostęp 29.08.2017].

Engelking Ryszard, Jak dziś czytać „Panią Bovary”, w: Gustaw Flaubert, Pani Bovary. $Z$ obyczajów prowincji, przeł. i posł. R. Engelking, słowo/obraz terytoria, Gdańsk 2005, s. 341-360.

Flaubert Gustave, Madame Bovary, extraits avec une notice sur la vie et l'art de Flaubert, une présentation et une analyse de $1^{\circ}$ oeuvre, une étude littéraire, des notes, des questions, des jugements et des thèmes de réflexion par Jacques Gautreau, Bordas, Paris 1987.

Flaubert Gustave, Pani Bovary, przekł. Aniela Micińska, przedmową poprzedził J. Parandowski, Państwowy Instytut Wydawniczy, Warszawa 1957.

Flaubert Gustave, Pani Bovary. Z obyczajów prowincji, przeł. i posłowiem opatrzył R. Engelking, słowo/obraz terytoria, Gdańsk 2005.

Gonçalves, Henriqueta Maria Almeida; Monteiro, Maria da Assunção Morais, Introdução à leitura de contos de Eça de Queirós, Almedina, Coimbra 2001.

Janion Maria, Kapelmistrz Kreisler i pani Bovary, w: Prace ofiarowane Henrykowi Markiewiczowi, red. T. Weiss, Wydawnictwo Literackie, Kraków-Wrocław 1984, s. 321-334.

51 E. de Queirós, Kuzyn Bazyli..., s. 55. 
Kalewska Anna, A fortuna cultural do Prefácio a "O Mandarim” de Eça de Queirós: a correspondência de Ladislao Mickiewicz e Oliveria Martins como factor de internacionalizacão de Eça, w: Congresso de Estudos Queirosianos IV Encontro Internacional de Queirosianos Actas, org. C. Reis i inn., Instituto de Língua e Literatura Portuguesas, Faculdade de Letras da Universidade de Coimbra 6 a 8 de Setembro de 2000, Almedina, Coimbra 2002, vol. 1, s. 379-391.

Kalewska Anna, Bettina von Arnim, Rilke i Mariana Alcoforado - o pozorności kobiecego dyskursu powieściowego, „Studia Niemcoznawcze” 2015, vol. 16, s. 295-309.

Klave Janina Z., Historia literatury portugalskiej. Zarys, Ossolineum, Wrocław 1985.

Klave Janina Z., Posłowie, w: Eça de Queirós, Kuzyn Bazyli, przeł. E. Reis, Wydawnictwo Literackie, Kraków 1978, s. 398-404.

Lis Renata, Ręka Flauberta, wyd. 2, przejrzane i popr., Wydawnictwo Sic!, Warszawa 2012.

Lourenço, António Apolinário, De "Madame Bovary" ao "Primo Basílio": a singularidade bovarista de Luísa, "Letras de Hoje" 2012, Porto Alegre (Brasil), 47 (4), s. 413-419, http://revistaseletronicas.pucrs.br/ojs/index.php/fale/article/view/12776 [dostęp 24.08.2017].

Łukaszyk Ewa, Imperium i nostalgia. „Styl późny” w kulturze portugalskiej, DiG, Warszawa 2015.

Moisés Massaud. 2004 (ed. revista e ampliada, $1^{\text {a }}$ ed. 1975). Dicionário de Termos Literários, São Paulo: Cultrix.

Moraes Rita Mara Netto de, A condição feminina no matrimônio, delineada pela ficção. Tese submetida ao Curso de Pós-Graduação em Literatura da Universidade Federal de Santa Catarina para a obtenção do grau de Doutora em Literatura. Orientadora: Profa. Dra. Odília Carreirão Ortiga, Universidade de Santa Catarina, Florianópolis 2009, ms, https://repositorio.ufsc.br/bitstream/ handle/123456789/92469/281158.pdf?sequence=1 [dostęp: 23.08.2017].

Nabokov Vladimir, Gustav Flaubert (1821-1880) Pani Bovary (1856), w: Wykłady o literaturze, przekł. Z. Batko, Muza S.A., Warszawa 2000, s. 185-244.

Parandowski Jan, Przedmowa, w: Gustaw Flaubert, Pani Bovary, Państwowy Instytut Wydawniczy, Warszawa 1957, s. 5-25.

Queirós, Eça de, Kuzyn Bazyli, przeł. E. Reis, Wydawnictwo Literackie, Kraków 1978.

Queirós Eça de, No Moinho. W: H.M. Almeida Gonçalves, M. da Assunção Morais Monteiro, Introdução de Contos de Eça de Queirós, 2a ed. revista, Almedina, Coimbra 2001, s. 142-153.

Queiroz Eça de, O Primo Bazilio. Episódio Doméstico, $17^{a}$ ed., fixação de texto e notas de Helena Cidade Moura, de acordo com a segunda edição (1878) precedida de uma carta inédita do Dr. José Maria d'Almeida de Queiroz a seu filho, Livros do Brasil, Lisboa s.d. [1953?]. 
Sand George, Listy do Flauberta, w: Eseje, przeł. S. Kożuchowska, M. Dramińska-Joczowa, Państwowy Instytut Wydawniczy, Warszawa 1958, s. 205-214.

Żurowski Maciej, „Pani Bovary” i rozwój powieści nowoczesnej, „Przegląd Humanistyczny" 1958, nr 4 (7), s. 17-45.

Anna Kalewska

\title{
Emma, Louise and the others, or the bovarism in Portugal and Brazil
}

\author{
Summary
}

The author uses the traditional methodology of literary history, making references to the critics of the myth and phantoms and the history of ideas. Based on the ideas of the theorists and writers of the West (George Sand, Charles Baudelaire, Vladimir Nabokov, Frederic Brown) and prominent Polish scholars (Maria Janion, among others), the author analyses the notion of le bovarysme within the realm of tragic "romantic dream taken out from romantic oeuvres" (MJ). The moral collapse of Emma Bovary and Luiza Mendonça as the heroines of Gustave Flaubert and Eça de Queiroz (in the novel Cousin Bazilio, 1878) would have a relation with the exhaustion of the pattern of the romantic poetics of dreaming (la revêrie) and with undertaking by the Portuguese and Brazilian writers of the tasks outlined before the realistic literature "of a thesis" - what is summoned up is the thesis of the susceptibility of a woman to adultery. The Lusopohone metamorphoses and continuations of Emma Bovary are in a close relationship with the literary creation of Eça de Queiroz (in the novel in question and in the tale In the Windmill) as well as of Machado de Assis - the predecessor of the Brazilian realism and of numerous writers who use Portuguese and Spanish in Europe and Latin America.

Keywords: the History of Ideas; poetics of la revêrie; French literature; le bovarysme; Lusophone literature 
Dr hab. Anna Kalewska, absolwentka Iberystyki, w latach 2012-2018 profesor UW, pracownik naukowy Instytutu Studiów Iberyjskich i Iberoamerykańskich UW. Zajmuje się literaturą portugalską, teatrem krajów języka portugalskiego oraz literaturą porównawczą. Opublikowała dwie książki: Camões, czyli tryumf epiki, Wydawnictwa Uniwersytetu Warszawskiego, Warszawa 1999 oraz Baltasar Dias i metamorfozy dyskursu dramaturgicznego w Portugalii i na Wyspach św. Tomasza i Książęcej. Esej historyczno-literacki i antropologiczny, Wydawnictwa Uniwersytetu Warszawskiego, Warszawa 2005. Przetłumaczyła m.in. powieść António Lobo Antunesa As Naus, Karawele wracają, WAB, Warszawa 2002. Uczestniczyła w wielu sympozjach krajowych i międzynarodowych, była kilkakrotnie stypendystką Instytutu Camõesa i Fundacji Gulbenkiana w Lizbonie. Należy do Międzynarodowego Stowarzyszenia Luzytanistów (A.I.L), Stowarzyszenia Luzytanistów Polskich (SLP), Towarzystwa Polsko-Brazylijskiego, Stowarzyszenia Studiów Ibero-Slawistycznych CompaRes i CLEPUL (z siedzibą w Lizbonie). Członekkorespondent CHAM (Centro de História de Além-Mar) Universidade Nova w Lizbonie i NETTCON (Universidade do Rio de Janeiro, Brazylia). Opublikowała sto kilkadziesiąt artykułów oraz prac badawczych i literackich w języku polskim i portugalskim (m.in. w „Ogrodzie”, „Tyglu Kultury”, „Twórczości”, „Literaturze na Świecie”, „Gazecie Wyborczej”, „Ameryce Lacińskiej”, „Studiach Iberystycznych”, „Veredas”, „Diacrítica”, „Acta Philologica”, „Itinerarios”, Projeções). Obecnie uczestniczy w realizacji międzynarodowego projektu naukowego Aprender Madeira (Learning about Madeira Islands) oraz O Feminino Luso/Polaco (CLEPUL/ CompaRes). Tłumacz przysięgły jęz. portugalskiego (znajomość innych języków: angielski, hiszpański, biernie francuski). Mieszka w Warszawie. 